\title{
Debt Capacity and Tests of Capital Structure Theories*
}

\author{
Michael L. Lemmon \\ David Eccles School of Business \\ University of Utah \\ email: finmll@business.utah.edu \\ Jaime F. Zender \\ Leeds School of Business \\ University of Colorado at Boulder \\ email: jaime.zender@colorado.edu
}

First Draft: 9/03/2001

Current Draft: 2/1/2009

\footnotetext{
*We are grateful for comments from John Graham, Roni Michaely, Robert McDonald, two anonymous referees, and participants in seminars at the University of Colorado, Cornell University, Claremont McKenna College, University of Washington, and the Australian National University. We are solely responsible for any remaining errors.
} 


\title{
Debt Capacity and Tests of Capital Structure Theories
}

\begin{abstract}
We examine the impact of explicitly incorporating a measure of debt capacity in recent tests of competing theories of capital structure. Our main results are that if external funds are required, in the absence of debt capacity concerns, debt appears to be preferred to equity. Concerns over debt capacity largely explain the use of new external equity financing by publicly traded firms. Finally, we present evidence that reconciles the frequent equity issues by small, high-growth firms with the pecking order. After accounting for debt capacity, the pecking order appears to be a good description of financing behavior for a large sample of firms examined over an extended time period.
\end{abstract}


An interesting discussion has been generated in recent studies designed to detect whether the tradeoff theory or the pecking order theory best describes the financing choices of corporations. The results presented here contribute to this literature. Based on a modified version of the Shyam-Sunder and Myers (1999) test that is shown to have power against relevant alternatives, we find that the pecking order theory provides a good description of financing behavior for a broad cross-section of firms examined over an extended time period.

Shyam-Sunder and Myers (1999) provide evidence, using a simple empirical model and a sample of 157 U.S. firms, suggesting that these firms largely act to fund their financing deficits with debt and conclude that the pecking order theory provides a good first-order approximation of their financing behavior. Consistent with this view, Fama and French (2002) report that short term variation in earnings and investment is mostly absorbed by debt. In contrast, Frank and Goyal (2003) show that Shyam-Sunder and Myers’ empirical findings supporting the pecking order do not survive when a broader sample of firms or a longer time series is used, wile Chirinko and Singha (2000) argue that the empirical test used by Shyam-Sunder and Myers has little power to distinguish among alternative financing schemes.

In this paper we modify the Shyam-Sunder and Myers test by accounting for heterogeneity in the level of debt capacity across firms. We show that these modifications provide our version of the Shyam-Sunder and Myers test with the power to discriminate between plausible alternative hypotheses. The results show that when firms must seek external funding, those most likely to be unconstrained by concerns over debt capacity primarily use debt to fill their financing deficits while those firms with limited debt capacity exhibit a heavy reliance on external equity financing.

Fama and French (2002) and Frank and Goyal (2003) also find that small, high-growth 
firms are the primary issuers of equity. Arguing that firms with the greatest potential for problems of asymmetric information will have the greatest incentive to follow the pecking order, Fama and French as well as Frank and Goyal conclude that finding large, mature firms (rather than small, high-growth firms) most closely follow the pecking order is contrary to the predictions of the pecking order theory.

We reexamine this argument. First by noting that the tension in Myers and Majluf (1984) (the foundation for pecking order behavior based on asymmetric information) is between the costs associated with asymmetric information concerning assets in place and the value of the firm's growth options relative to the value of its assets in place. While small firms are likely to be associated with larger amounts of asymmetric information they are also likely to have growth options that are larger in value relative to assets in place compared to those of large firms. Moreover, we show that it is precisely the small, high-growth firms that also face the most restrictive debt capacity constraints. These arguments suggest that the frequent equity issues by smaller firms do not necessarily contradict pecking order behavior.

Empirically, we provide evidence on this question first by examining differences in the characteristics of firms that issue equity compared to non-issuers across groups of firms segmented on the likelihood of being constrained by debt capacity. And second, by considering differences in the costs associated with announcements of equity issues (which have been argued to be the result of asymmetric information) again comparing constrained versus unconstrained firms. For the group of firms most likely to be constrained by debt capacity we find that the issuers of significant amounts of equity are, on average, growing very fast (average growth in assets is $49.8 \%$ annually as compared to $10.6 \%$ for non-issuers) and losing money (average ROA is -0.024 compare to 0.107 for non-issuers). Equity issuers in this group also have relatively low 
leverage prior to the issue. However, the predicted leverage change (the change in the firm's book leverage ratio that would occur if its financing deficit was completely financed with debt) is $29 \%$, indicating that if these firms used only debt financing their debt ratios would on average increase from about $13 \%$ to over $42 \%$. Given their growth rates and negative profitability, such an increase in leverage would likely violate any reasonable expected level of debt capacity.

In contrast, equity issues by firms that are ex ante less likely to be concerned about debt capacity face a different set of constraints. While these firms should be less likely to be rationed by lenders, they may be reluctant to pursue further borrowing because they are unable to support additional debt. Consistent with this view, equity issuers in this group are growing much more rapidly and have significantly higher leverage prior to the issue than similar non-issuers.

Finally, evidence from announcement effects for new equity issues also shows that firms most likely to be constrained by concerns over debt capacity face lower costs of equity issues than do unconstrained firms. On average, firms facing debt capacity constraints (generally small, high growth firms) see significantly less negative market reactions to announcements of equity issues when compared to unconstrained (generally large, mature) firms. Overall the evidence suggests that the frequent equity issues by young high growth firms are consistent with the existence of debt capacity constraints do not contradict a version of the pecking order that recognizes limits to the use of debt financing.

The remainder of this paper is organized as follows. Section 1 describes prior tests of the pecking order and develops our hypotheses. Section 2 describes our data. Section 3 presents our main results on the effect of controlling for debt capacity. Section 4 examines the intuition that firms facing greater amounts of asymmetric information should follow the pecking order more closely. Section 5 concludes. 


\section{Tests of Capital Structure Theory}

The tradeoff theory of capital structure predicts that firms will choose their mix of debt and equity to balance the costs and benefits of debt. Tax benefits and control of free cash flow problems are argued to push firms to use more debt, while bankruptcy and other agency costs provide firms with incentives to use less. The theory describes a firm's optimal capital structure as the mix of financing that equates the marginal costs and benefits of debt. In static versions of the tradeoff model these forces determine an optimal capital structure. In dynamic versions of the model (e.g. Fisher, Heinkel, and Zechner (1989)) the optimum is characterized as an interval, and violation of the endpoints of the interval lead to revisions in the firm's financing mix.

Myers (1984), based on Myers and Majluf (1984), presents a pecking order theory of financing choice. The defining prediction of the model is that firms will not have an optimal capital structure, but will instead follow a pecking order of incremental financing choice that places internally generated funds at the top of the order, followed by debt, and finally, when the firm reaches its “debt capacity,” external equity. This theory is based upon costs derived from asymmetric information between managers and the market and the assumption that tradeoff theory costs and benefits of debt financing are of second order importance when compared to the costs of issuing new securities in the presence of asymmetric information. The development of a pecking order based upon costs of adverse selection requires an ad hoc specification of the manager's incentive contract (Dybvig and Zender (1991)) and some limitation on the types of financing strategies that may be pursued (e.g. Brennan and Kraus (1987)). Despite these theoretical criticisms, the pecking order remains a predominant theory of financing choice.

In a recent set of papers, tests designed to distinguish between the pecking order and 
tradeoff theories have been developed. Shyam-Sunder and Myers (1999) introduce a test of the pecking order theory. Their test is based on the pecking order's prediction concerning the type of external financing chosen to fill the "financing deficit." The financing deficit is defined, using the cash flow identity, as the growth in assets less the growth in current liabilities (except the current portion of long term debt) less the growth in retained earnings. According to the identity, this deficit must be “filled” by the (net) sale of new securities. Shyam-Sunder and Myers argue that, except for firms at or near their debt capacity, the pecking order predicts that the deficit will be filled entirely with new debt issues. The empirical specification of their test is:

$$
\Delta D_{i t}=\alpha+\beta_{P O} D E F_{i t}+\varepsilon_{i t}
$$

where $\Delta D_{i t}$ is the net debt issued by firm $i$ in period $t$, and $D E F_{i t}$ is the corresponding financing deficit.

Shyam-Sunder and Myers argue that the pecking order predicts $\alpha=0$ and $\beta_{P O}=1$. Intuitively, the slope coefficient in this regression indicates the extent to which debt issues cover the financing deficit. They acknowledge that $\beta_{P O}$ may be less than 1 for firms near their debt capacity, however, the large mature firms in their sample are not likely to face such a constraint. They find $\beta_{P O}=0.75$ with an $\mathrm{R}^{2}$ of 0.68 (see column 2 of their Table 2) when they estimate equation (1). They interpret this as evidence that "the pecking order is an excellent first-order descriptor of corporate financing behavior” (Shyam-Sunder and Myers (1999) pg.242) for their sample. They also find that a target adjustment model based on the tradeoff theory has little power to explain the changes in debt financing for these firms.

This paper has generated an interesting discussion. Chirinko and Singha (2000) illustrate, via several examples, that the Shyam-Sunder and Myers test has little power to distinguish 
between plausible alternative financing hierarchies. Frank and Goyal (2003) question the conclusions drawn by Shyam-Sunder and Myers (1999) on several fronts. The most interesting challenges are whether the Shyam-Sunder and Myers findings hold for a broader sample of firms, whether the results hold over a longer time horizon (in particular including the 1990's) and whether their findings hold for subsamples of firms predicted to have high levels of asymmetric information. For an expanded sample of firms, Frank and Goyal show that the estimate of $\beta_{P O}$ in equation (1) is much smaller than one and is even smaller in the 1990's. Moreover, they find that the pecking order performs the worst for small firms, which they argue should have the greatest degree of asymmetric information and therefore the strongest incentives to follow the pecking order.

Fama and French (2002) examine many of the predictions of the tradeoff and the pecking order theories with respect to capital structure and dividend policy. They argue that for the majority of the predictions the two theories agree and generally report findings consistent with these shared predictions. Consistent with Shyam-Sunder and Myers (1999), Fama and French (2002) find that debt is used to address variations in investment and earnings in the short-term. However, they also find, as in Frank and Goyal (2003), that small, high-growth companies issue most of the equity (see also Fama and French (2005)). Fama and French join Frank and Goyal in arguing that this finding contradicts the pecking order theory. Leary and Roberts (2007) also question the ability of the pecking order to explain financing decisions. Using a different empirical approach, they find little support for the pecking order, even for subsamples of firms for which they argue the pecking order should be most likely to hold.

Determining what lies behind these contrasting findings is important for furthering our understanding of capital structure and financing choices of firms. We provide new evidence in 
an attempt to reconcile some of these findings by focusing on the role of debt capacity; an important element of the pecking order hypothesis that has been largely ignored in existing empirical tests.

\subsection{Empirical Strategy}

As discussed above, the Shyam-Sunder and Myers test, while very intuitive, has little power to distinguish between alternative hypotheses. Accordingly, we modify the ShyamSunder and Myers test in two ways. First we separately examine firms that are expected to be constrained by concerns over debt capacity and those that are not. In this way we exploit the cross sectional heterogeneity in debt capacity in the sample. The contrast in results across these two groups is an important aspect of our empirical design. Second, we include as an additional independent variable; the square of the financing deficit:

$$
\Delta D_{i t}=\alpha+\beta_{P O} D E F_{i t}+\gamma D E F_{i t}^{2}+\varepsilon_{i t}
$$

As Chirinko and Singha (2000) illustrate, under the pecking order the relation between the change in debt and the financing deficit when firms face debt capacity constraints is concave. We include the square of the financing deficit to capture the concave nature of the relation and to more fully identify the nature of the financing hierarchy by considering the differences in financing choice between large and small deficits.

For firms that follow the pecking order and are unconstrained by concerns over debt capacity, the original Shyam-Sunder and Myers test (equation (1)) should perform very well (a $\beta_{P O}$ coefficient estimate near 1 and a high R-squared). Furthermore, there should be little change in results when equation (2) is instead estimated. A slack debt capacity constraint will imply that both small and large deficits will be financed with debt. In contrast, for pecking order firms that are constrained by concerns over debt capacity, the test in equation (1) should perform 
"poorly" with an estimate of $\beta_{P O}$ that is far from 1 (see Chirinko and Singha (2000)) and a low R-squared. For such firms, however, estimating equation (2) should result in an estimate of the $\gamma$ coefficient that is negative and significant, an increase in the estimate of the $\beta_{P O}$ coefficient, and an increase in the R-squared of the regression relative to equation (1). Pecking order firms that are constrained by debt capacity will use debt to fill small financing deficits (those that do not violate the firm's debt capacity constraint) but for larger deficits these firms will turn to equity financing. Note that the sign the coefficient $\gamma$ indicates the nature of the financing hierarchy.

To demonstrate the ability of our tests to identify pecking order behavior in the presence of concerns over debt capacity and to distinguish between competing hypotheses we provide evidence generated using simulated data. We closely follow Leary and Roberts (2007) in simulating the financing behavior of firms. We simulate data for two types of firms. The first set of firms is relatively unconstrained by concerns over debt capacity, while the second set of firms faces more binding debt capacity constraints. To make the simulations directly comparable to our empirical results we use the actual financing deficits in the data and simulate debt capacities and financing behavior. Specifically, for each firm-year observation of the financing deficit we simulate a value for the firm's unused debt capacity. To simulate financing behavior we compare the size of the financing deficit to the simulated value of the firm's debt capacity. If the size of the financing deficit is less than the remaining debt capacity, the deficit is assumed to be filled entirely with debt. If the financing deficit exceeds the remaining debt capacity of the firm, then the firm is assumed to issue debt up to the point where the firm's debt capacity is 
exhausted and is assumed to fill the remainder of the deficit using equity. ${ }^{1}$

As a basis for comparison we also simulate financing behavior under two alternative financing assumptions. The first alternative is that financing policies are simply random in the sense that a coin flip determines whether the firm issues either debt or equity, where the probability of a debt issue in a given year is set to match the average frequency of debt issues in the two subsamples. Chang and Dasgupta (2008) show that random financing can replicate a number of stylized facts related to target adjustment behavior and conclude that a number of standard tests of target adjustment behavior have little power to reject alternative explanations for financing behavior. We consider the performance of our test on data generated by random financing to see if the same criticism can be applied. Intuitively, our test should have power to reject the pecking order under random financing since the coefficient on the square of the financing deficit should be insignificant as the size of the deficit in this setting is unrelated to the choice of security the firm will issue. For the second alternative we simulate data assuming that financing is generated by a partial adjustment model of the form:

$$
\frac{D_{i t}}{A_{i t}}=\lambda\left(k-\frac{D_{i t-1}}{A_{i t-1}}\right)+\varepsilon,
$$

where $\lambda$ is the speed of adjustment and $k$ is the target leverage ratio. The financing behavior generated by the partial adjustment model is consistent with the tradeoff theory, where firms issue securities in order to move toward some target leverage ratio. We, therefore, follow

\footnotetext{
${ }^{1}$ Note that our financing scheme differs slightly from that used by Leary and Roberts (2007) to simulate pecking order behavior in their paper. In their simulations, Leary and Roberts treat debt capacity by assuming that if by covering the deficit for a firm entirely with debt will violate that firm's debt capacity, the entire deficit is covered with an equity issue instead. In contrast to this assumption, however, dual issues make up a significant portion of external financing in our sample. Leary and Roberts (2007), report that only a tiny fraction of the issues in their sample are dual issues. This appears to be due to their identification scheme requiring an "issue" of debt or equity to amount to a change in assets of at least $5 \%$. Dual issues are therefore associated with firms raising new capital in excess of $10 \%$ of existing assets, making them a relatively rare event in the data.
} 
Shyam-Sunder and Myers (1999) and consider whether our test can reject the pecking order when a tradeoff model has generated the data.

For each of these alternative financing arrangements (random or partial adjustment) firms are separated into two groups, those with high levels of debt capacity and those with low levels of debt capacity, based on our empirical proxy for debt capacity described in Section 2.1. Within each group, the simulations are calibrated to yield financing behavior that matches the moments of actual debt issuance in the data for that group. The simulation procedure is described more completely in the appendix.

Table 1 presents the results of our tests using the simulated data. We estimate equations (1) and (2) to illustrate how our augmented version of the Shyam-Sunder and Myers test discriminates among the alternative hypotheses for financing behavior. Panel A presents the results for the firms assumed to be following the pecking order. We first examine the performance of the original Shyam-Sunder and Myers test (equation (1)). The first and third columns in the table present the results. Two features are worth noting. First, despite the fact that the data for both sets of firms was generated by pecking order behavior, the model fits much better for those firms with high levels of debt capacity. For this set of firms, the R-squared of the regression is $82 \%$ and the slope coefficient on the financing deficit is 0.77 . The results of the simulation closely match the findings of Shyam-Sunder and Myers (1999). Second, also as predicted, for the firms with a tight debt capacity constraint the model in equation (1) fits much worse. The R-squared is $34 \%$ and the slope coefficient is only 0.32 . This result closely matches the findings for small firms presented in Frank and Goyal (2003).

Panel B presents the results of estimating equation (1) on the data generated by random financing. Comparing these results to the same columns in Panel A illustrates the critique of the 
Shyam-Sunder and Myers test raised by Chirinko and Singha (2000). In particular, the coefficient estimates on the financing deficit for both groups of firms mirror those presented in Panel A. Even when we separately examine firms with high and low levels of debt capacity, estimating equation (1) alone has no power to distinguish pecking order from random financing behavior. Panel C presents the results based on the simulated data from the partial adjustment model. For both groups of firms, the Shyam-Sunder and Myers test performs poorly. The slope coefficients on the financing deficit are close to zero (although they are statistically significant at the $1 \%$ level) and the R-squared of the regressions is very small. The difference in the results of estimating equation (1) on the simulated data based on random financing and the partial adjustment model arises from the fact that under random financing, the financing deficit is filled entirely with either debt or equity depending on the outcome of the coin flip, while under the partial adjustment model, the firm chooses the mix of securities to issue that moves the firm toward its target debt ratio. Based on these results, it appears that the basic Shyam-Sunder and Myers test can discriminate between the pecking order and financing generated under the tradeoff theory, but cannot discriminate the pecking order from random financing behavior. ${ }^{2}$

The second and fourth columns in panels A, B, and C present the results of estimating equation (2) using the simulated data. As seen in the table, the addition of the square of the financing deficit as an explanatory variable in the regression results in a test that can distinguish pecking order behavior from random financing. For low debt capacity firms that follow the pecking order, the addition of the square of the financing deficit has two effects. First, the coefficient on the financing deficit increases substantially rising from 0.32 (column 1 ) to 0.54

\footnotetext{
${ }^{2}$ Shyam-Sunder and Myers (1999) also find that their pecking order test performs poorly on data simulated from a partial adjustment model. The results in panel C extend their findings by simulating data for a much broader sample of firms and confirm their conclusions.
} 
(column 2). This indicates that, as constructed, smaller deficits are more likely to be filled using debt because financing a small deficit with debt is unlikely to violate the firm's debt capacity constraint. Second, the coefficient on the square of the deficit is -0.23 and is statistically significant, indicating a concave relation between net debt issues and the financing deficit. The concavity in this relationship arises because firms facing debt capacity constraints fill larger deficits with issues of equity. ${ }^{3}$ When firms follow random financing or a partial adjustment model, the addition of the squared deficit has little effect on the results obtained using the basic Shyam-Sunder and Myers specification in equation (1). Under neither alternative does the size of the financing deficit have a predictable relationship with the choice of financing.

For pecking order firms with high levels of debt capacity (panel A, column 4) the addition of the square of the financing deficit has almost no impact. The coefficient on the financing deficit does not change appreciably and the coefficient on the square of the deficit, while negative is economically small and is not significantly different from zero. For firms with high debt capacities, both small and large deficits tend to be filled using debt issues. As with the low debt capacity firms, when firms follow random financing or a partial adjustment model, the addition of the squared financing deficit has little effect on the results.

Finally, note that the coefficient on the squared deficit can also discriminate pecking order behavior from two other financing alternatives described by Chirinko and Singha (2000). First, if the financing hierarchy is reversed, such that small financing deficits are filled using equity and large deficits are filled with debt, then the relationship between debt issues and the financing deficit will be convex and the coefficient on the square of the financing deficit will be

\footnotetext{
${ }^{3}$ Leary and Roberts (2007) also find that the coefficient on the square of the financing deficit is negative when a sufficient fraction of firms in their simulations are assumed to follow the pecking order. In their simulations, however, they do not examine differences in this coefficient as a function of debt capacity, which is our focus.
} 
positive. Second, if the firm always issues debt and equity in fixed proportions, then the size of the deficit does not affect financing and the coefficient on the square of the deficit will be zero.

In summary, the simulations demonstrate the importance of controlling for the level of debt capacity in the Shyam-Sunder and Myers test and the usefulness of including the square of the financing deficit as an additional explanatory variable in providing the test with the power to discriminate amongst competing hypotheses for incremental financing decisions.

\subsection{Debt Capacity}

Debt capacity was originally defined by Myers (1977) as the point at which an increase in the use of debt reduces the total market value of the firm's debt. More recently, Myers (1984), Shyam-Sunder and Myers (1999) and Chirinko and Singha (2000) define it as "sufficiently high" debt ratios so that costs of financial distress curtail further debt issues. The combination of debt capacity defined in these terms and the pecking order theory suggests that costs of adverse selection are dominant for "low to moderate" leverage levels but that tradeoff-theory-like forces become primary motivators of financing decisions at "high” levels of leverage.

Bolton and Freixas (2000), in a model that is very closely related to the theory underlying the pecking order, provide an empirically implementable description of debt capacity. They present a model of financing choice in which the main friction is asymmetric information between the firm and the market. In their model, firms may raise external financing using equity, bank debt, or via the public bond market. There is an informational dilution cost to issuing equity in the presence of asymmetric information as in Myers and Majluf (1984). When issuing debt, firms may choose between bank debt and public bonds. Banks have an advantage in minimizing costs of financial distress, but face their own intermediation costs that are passed on to the borrower, so bank debt is nominally more expensive than public debt (See also, 
Cantillo and Wright (2000)). Bonds carry a lower interest rate, but borrowers in the public debt market face higher costs if they become distressed.

The Bolton Freixas model results in a market segmentation in which the safest firms use the public debt market for financing, these firms have the greatest capacity to borrow, a very low probability of distress and so it is cost effective for them to avoid the intermediation costs incurred with bank debt. More risky firms with a lower capacity to borrow use the more flexible but nominally more expensive bank debt. Bank debt provides the cheapest form of flexible financing. The riskiest firms are constrained to use equity (or are unable to obtain any outside funding). The interplay between the supply and demand for funds causes the market segmentation as firms sort themselves according to their capacity to use debt financing and their demand for flexibility in distress. Based on this segmentation a firm's ability to issue public (rated) debt indicates a large debt capacity. Conversely, the use of bank (monitored) debt indicates a lower debt capacity. Furthermore, Bolton and Freixas also suggest measures of firm risk or firm age as alternative proxies for debt capacity.

Holmstrom and Tirole (1997) also provide a model in which the presence or absence of public or rated debt is related to the firm's level of debt capacity. In the Holmstrom and Tirole model, the financing choice is limited to bank debt or public debt and the fundamental friction is a managerial moral hazard problem rather than asymmetric information. In their model, a firm's debt capacity is determined by its available collateral. In equilibrium, firms with the highest level of debt capacity borrow in the public debt markets while firms with low levels of debt capacity turn to intermediated (monitored) financing. Holmstrom and Tirole point out that a firm's debt capacity may be driven by demand and/or supply side considerations. On the demand side, firms with low levels of collateral have relatively low demand for debt financing 
and seek intermediated or monitored debt while firms with high levels of collateral use direct or public debt. On the supply side lenders may ration borrowers (Stiglitz and Weiss (1981)) ${ }^{4}$ when credit markets tighten.

Finally, it is worth noting that limited debt capacity is simply one form of financing constraint. Consistent with a firm's use of public debt as an indication of debt capacity, Whited (1992), Carpenter, Fazzari, and Peterson (1998), Almeida, Campello and Weisbach (2002), and many others have used the existence of a bond rating as an empirical measure of whether firms face financing constraints in the external financial markets.

Our primary indicator of debt capacity is therefore whether the firm has, based on its underlying characteristics, a high likelihood of being able to access the public debt markets. Firms that can access the bond market have cash flows that are sufficiently stable, sufficiently large pools of existing collateral, and sufficient informational transparency to allow access to relatively large amounts of arms-length debt. They also borrow in a market for which the interest rate is more likely to equilibrate the supply and demand for capital. This is the implicit assumption concerning the debt market made by Myers and Majluf (1984), and so firms that are able to issue arms-length debt most closely conform to the assumptions underlying the pecking order. In contrast, firms without the ability to access public debt markets do not share these characteristics, and must (for the most part) borrow via loans from banks or other financial intermediaries. These firms are smaller, have more volatile cash flows, fewer tangible assets and are more opaque, and thus are likely to demand lower levels of debt financing compared to firms with rated debt. Furthermore, firms that borrow from "relationship lenders" are most likely to be subject to an externally imposed debt capacity in the form of rationing (Faulkender and Peterson

${ }^{4}$ Hellman and Stiglitz (2003) model the impact of asymmetric information on the debt and equity markets. 
(2006)) and to face high reorganization costs (Cantillo and Wright (2002)).

While the presence (or absence) of rated debt provides an indication of the extent to which a firm has access to relatively low cost borrowing and so suggests a relatively large (or small) debt capacity, the use of the actual presence or absence of a bond rating as a measure of debt capacity is problematic. We are particularly worried about firms without bond ratings that have chosen to rely on equity financing for reasons outside of the pecking order despite having the capacity to issue rated debt. To identify such firms as being constrained by concerns over debt capacity is a mistake, and would bias our results in favor of the pecking order. To minimize these concerns we use a predictive model of whether a firm has a bond rating in a given year as the primary indication of the extent of a given firm's debt capacity.

A final complication is that it is the distance a firm is from its debt capacity that is of interest. This distance is difficult to measure and the likelihood of having rated debt is a relatively noisy proxy of this quantity. However, to the extent that our proxy misclassifies firms with a large debt capacity but high current leverage as being unconstrained by concerns over debt capacity or firms with small debt capacity but little or no leverage as being constrained, its use will generate a bias against the predicted outcomes.

\section{Data}

The data consist of all firms on both the CRSP and Compustat databases for the period 1971-2001. We begin in 1971 because we require flow of funds data to compute the financing deficit and this data is not available prior to 1971. Using the flow of funds data, we follow Frank and Goyal (2003) and compute the financing deficit as the sum of internal cash flow, the change 
in working capital, investments, and cash dividends. ${ }^{5}$ By definition, the financing deficit is equal to the sum of net debt (data 111 - data 114) and equity issues (data 108 - data 115). In contrast, Shyam-Sunder and Myers (1999) also include the current portion of long-term debt as part of the financing deficit beyond its role in the change in working capital. Frank and Goyal find empirically that the current portion of long-term debt should not be included as part of the deficit, and we follow their definition here. We exclude regulated (SICs 4900-4999) and financial (SICs 6000-6999) firms and firms with minimum total assets less than $\$ 1$ million or minimum sales less than zero. We further exclude individual firm-years with missing values for the financing deficit and net debt or equity issues. The financing deficit and net security issues are scaled by book assets (data 6) at the end of the previous year. In order to reduce the impact of outliers on the results, we eliminate firm-year observations for which the absolute values of the financing deficit or net issues of debt or equity are greater than $200 \%$ of the firm's total book assets at the end of the previous year. ${ }^{6}$ For each firm year, we also compute leverage as the ratio of long-term debt (data $9+$ data 44$)$ to total assets.

We also use a number of variables that have been identified as affecting leverage in the previous literature on capital structure (e.g., Rajan and Zingales (1995), Frank and Goyal (2003), and Fama and French (2002)). Asset tangibility is measured as the ratio of property plant and equipment (data 8) to total assets. Firms with more tangible assets are expected to have lower costs associated with financial distress. The market-to-book ratio ((data 6-data 60+data $24 *$ data

\footnotetext{
${ }^{5}$ The individual Compustat variables used to compute the components of the deficit vary by format code (as reported in Compustat). See Frank and Goyal (2003) for details on computing individual components of the financing deficit.

${ }^{6}$ In addition to trimming the data based on variables computed from the statement of cash flows, we also eliminate firm-year observations with large changes (>200\%) in the financing deficit, and net debt and equity issues computed based on changes in balance sheet quantities. The exclusion of these restrictions has no material effect on our conclusions.
} 
25)/data 6) is used as a proxy for growth opportunities. Myers (1977) argues that firms with more growth opportunities have a greater potential for underinvestment problems arising from the use of debt. Profitability is measured as the ratio of operating profits (data 13) to total assets. Prior research has found an inverse correlation between profitability and leverage, which has often been interpreted as evidence in favor of the pecking order (e.g., Fama and French (2002)). As a proxy for the volatility of a firm's cash flow in a given year we use the volatility of that firm's daily stock returns during the year. Cash flow volatility and stock price volatility should be tied by pricing in the equity market. Empirically, for a subset of firms with sufficient data to accurately measure cash flow volatility, we find that the rank correlation between these two volatility measures is $0.53 .^{7}$ All else equal, a firm with more volatile cash flows can borrow less either because the debt overhang problem (Myers (1977)) is more severe or because it is more likely to be unable to meet the payments on its debt obligations.

Finally, firm age is measured as the age of the firm relative to the first year the firm appears on Compustat. We also create a variable indicating whether a firm has a senior debt rating assigned by S\&P in a particular year as recorded by Compustat. This variable (data 280) is only available beginning in 1986. Our final sample is comprised of 67,203 firm-year observations.

\subsection{Measuring Debt Capacity}

As discussed above, our main measure for debt capacity is based on the likelihood that a firm can access public debt markets. In order to measure this likelihood we estimate a logit model in which the dependent variable is one if a firm has debt rating in a particular year and

\footnotetext{
${ }^{7}$ Measuring cash flow volatility directly is problematic because in a given year many firms will have relatively few past observations of cash flow with which to estimate its volatility. Using quarterly Compustat data we compute the volatility of a firm's return on assets for a subsample of our firms using at least 8 and as many as 12 quarters of data.
} 
zero otherwise. The estimation uses data from 1986-2001; the part of our sample period for which bond ratings are available in Compustat. The firm characteristics used in the logit regression are firm size (log of total assets), profitability (ROA), the fraction of total assets that are tangible, the market to book ratio, leverage, firm age (the natural log of the number of years since the firm first appeared on Compustat), the standard deviation of stock returns, and, in one version, industry dummies for each 2-digit SIC code in the sample. ${ }^{8}$ All of the independent variables are lagged one period.

Smaller and younger firms are likely to have a shorter track record and be more opaque from the standpoint of lenders, suggesting that they will be less likely to have bond ratings. Smaller firms also face proportionally higher fixed costs of issuing bonds in the public debt markets (e.g., Altinkilic and Hansen (2000)). To the extent that relationship lenders are more efficient at ex post monitoring and restructuring in the event of distress (e.g., Cantillo and Wright (2000)), we expect that firms that are likely to face higher costs of financial distress and distortions to their investment policy, such as those with high volatility, fewer tangible assets, and high market-to-book ratios, will be less likely to be able to obtain a bond rating. Finally, all else equal, more profitable firms are better able to make required payments to debtholders and so can support more debt, and firms with more debt outstanding have proven their ability to borrow.

Table 2 presents the results of the logit regressions. Robust t-statistics clustered by firm (Petersen (2008)) are reported in parentheses below the regression coefficients. Model (1) shows that firm size, firm age, the standard deviation of stock returns, the market-to-book ratio, and leverage have the expected signs and all are significant predictors of the likelihood that a firm has a bond rating. The financial constraints literature also identifies firm size and firm age as 
proxies for the general level of financing constraints facing a firm, lending further support to the use of our model for the likelihood of having rated debt as a measure of whether a firm is constrained or unconstrained by concerns over debt capacity. The model fit as measured by the pseudo R-squared is 52\%. Model (2) shows that inclusion of industry effects improves the fit of the model only slightly.

The estimated coefficients (based on data from 1986-2001) from Model (1) are used to obtain an estimated probability that a given firm could obtain a bond rating for each year in the period 1971-2001. Beyond minimizing the potential bias associated with using the actual presence of rated debt, this approach also allows us to begin our sample period in 1971 (when the statement of cash flow data becomes available) rather than in 1986 (when bond ratings are first reported in Compustat). In each year we form terciles based on the predicted probability of having a bond rating. The low tercile contains firm-years in the lowest third of predicted probabilities of having a bond rating based on their characteristics, and the high tercile contains firms in the highest third of predicted probabilities of having a bond rating.

Table 3 presents summary statistics for subsamples of firms based upon whether they have a low (bottom tercile) or a high (top tercile) probability of being able to access the public bond market. The data is consistent with the idea that concerns over debt capacity drive financing behavior. The most notable differences between the subsamples are that, firms with a high probability of having a bond rating have lower average financing deficits, finance these deficits much more heavily with debt financing, and on average grow more slowly than firms with a low probability of having a bond rating. The lower growth rates and smaller financing deficits for firms in the high predicted bond rating group means that these firms can finance a

${ }^{8}$ The independent variables are similar to those used in a Faulkender and Peterson (2006). 
larger proportion of their current financing deficits with debt without significantly increasing their leverage ratios (and in doing so approach their debt capacities much more slowly), while firms in the low predicted bond rating group would experience a significant change in their leverage ratios by issuing debt to fund their financing deficits. To illustrate this concretely, we calculate a variable labeled predicted leverage change that measures the change in leverage that would occur if firms financed their entire deficit with debt. Table 3 shows that, on average, firms in the high predicted rating group would see their leverage ratios increase by $1.0 \%$ if they followed a strict pecking order, while those in the low predicted bond rating group would see an annual increase in their leverage ratios of $6.5 \%$ on average. In contrast, the actual average leverage changes for firms in these two groups are $-0.1 \%$ and $1.4 \%$, respectively.

\section{Testing the Pecking Order with Debt Capacity}

We now present tests of the pecking order that explicitly account for heterogeneity in debt capacity using our predicted ratings groups and the augmented Shyam-Sunder and Myers regression (equation 2). Under the pecking order, holding the size of the financing deficit constant, firms with less restrictive debt capacity constraints will, on average, use more debt to satisfy their external financing needs. Holding debt capacity constant, firms should use debt to fund small deficits, but will increasingly turn to equity when external financing needs are large.

Table 4 presents the results of these tests. The first column in the table presents the results of the basic Shyam-Sunder and Myers test of the pecking order on those firms most likely to be constrained by debt capacity considerations (those in the low predicted bond rating group). As expected, the Shyam-Sunder and Myers test performs particularly poorly for this set of firms. The estimate of the slope coefficient on the financing deficit is only 0.30 and the R-squared 
indicates that the financing deficit explains only $29 \%$ of the variation in net debt issues.

The second column in Table 4 considers the same firms but extends the Shyam-Sunder and Myers test by including the squared deficit as an additional independent variable in order to consider differences in the behavior of firms facing "small" and "large" financing deficits. The results are consistent with the predictions of the pecking order theory in the presence of concerns about debt capacity. The slope coefficient on the financing deficit increases substantially to 0.53, indicating that "small” deficits are financed by about half debt and half equity on average. The coefficient estimate on the squared deficit is -0.24 , indicating a much greater reliance on equity financing when deficits are "large". The R-squared of the regression increases to 34\%.

An interesting contrast to these results is presented in the final two columns of Table 4, which examines the subsample of firms with the highest likelihood of having a bond rating. These columns show that for a large cross-section (and a long time series) of firms that are predicted not to face debt capacity constraints, the financing deficit explains debt issues very well. In the basic Shyam-Sunder and Myers test, the slope coefficient is 0.76 and the R-squared is $75 \% .{ }^{9}$ When the squared deficit is included, the slope coefficient on the deficit increases to 0.79. The coefficient on the squared financing deficit is significantly negative but is small in magnitude (-0.06), indicating that, for those firms least likely to be constrained by debt capacity, debt is the primary security used to fill the financing deficit, even for "large" deficits.

The medium predicted rating group exhibits behavior that lies between that of the low and high predicted rating groups. Overall, the results presented in Table 4 indicate that the use of debt and equity across groups conforms well with the predictions of the pecking order theory

\footnotetext{
${ }^{9}$ In contrast to Frank and Goyal (2003), we find little evidence that, for firms unconstrained by debt capacity, the pecking order performs worse in the latter half of the sample period. For firms in the high predicted rating group, the slope coefficient in the regression is 0.79 in the pre 1986 period and 0.75 in the post-1986 period.
} 
after accounting for the effect of debt capacity. The more restrictive is a firm's debt capacity constraint the greater the firm's observed dependence on external equity financing. Further, for a given level of debt capacity, the firm's reliance on external equity financing increases with the size of the financing deficit. Finally, it is worth noting that the results closely mirror those presented previously in Table 1 using the simulated financing data that assumes firms follow the pecking order in the presence constraints imposed by concerns over debt capacity.

To explore the robustness of these findings, Table 5 reports the results from estimating equation (2) on subsamples that exclude firm-years with negative financing deficits, firm-years with negative profitability, and firm-years with a high likelihood of financial distress. If firms with negative financing deficits tend to retire debt, this could bias upward the coefficient on small financing deficits. The first two columns in Table 5 show that excluding firm-years with negative financing deficits has little effect on the results compared to those reported in Table 4. Unprofitable firms and firms currently facing financial distress will likely have larger financing deficits because they have low levels of internal funds and these firms will also be forced to turn to equity financing. To assess whether our results are driven by unprofitable financially distressed firms, we exclude firm-years with negative return on assets and firm years in the highest tercile of the likelihood of financial distress as measured by Altman's z-score. The results are reported in the last four columns in Table 5. In both cases, the additional data exclusions have little effect on the results.

Finally, we assess whether our results are merely a manifestation of differences in firm size. Almeida and Campello (2007) show that most large firms have bond ratings while most small firms do not and it is possible that differences in firm size proxy for financing constraints that are unrelated to debt capacity. To explore this possibility we first divide the sample into 
small firms and large firms based on the sample median value of total assets in each year. Then within each firm size group, we rank firms into terciles based on the predicted probability of having a bond rating. These sorts allow us to examine the effects of debt capacity on financing behavior while holding firm size constant. The results are reported in Table 6 .

Panel A reports the results for small firms. As seen in the table, the results mirror those based on the full sample. For small firms with a low likelihood of having a bond rating, the coefficient on the financing deficit is 0.48 and the coefficient on the squared financing deficit is -0.22. In comparison, for small firms with a high likelihood of having a bond rating, the coefficient on the financing deficit is 0.69 and the coefficient on the squared financing deficit is -0.047 and is just statistically significant at the $10 \%$ level.

The results for large firms are reported in Panel B. In large firms with a low probability of having a bond rating, the coefficient on the financing deficit is 0.66 and the coefficient on the squared financing deficit is -0.04 , but is not statistically significant. In large firms with a high likelihood of having a bond rating, the coefficient estimate on the financing deficit increases to 0.79 and the coefficient estimate on the squared financing deficit is 0.014 , but is not statistically significant.

Overall, the results provide additional evidence that is consistent with the predicted effects of debt capacity concerns on financing behavior, even after controlling for the effects of general financing constraints (as proxied by firm size). Furthermore, these findings also highlight the importance of using the predicted probability of obtaining a bond rating rather than the actual existence a rating to classify firms facing debt capacity constraints. In particular, among small firms that have a high likelihood of having a bond rating based on the logit model in Table 2, only $2 \%$ actually have bond ratings. Nevertheless, as shown above these firms rely 
much more heavily on debt financing compared to small firms that are less likely to be able to issue public debt, suggesting that they have access to relatively low cost debt financing despite their small size and the fact that they do not borrow in the public debt markets. One reason these firms may not access public debt markets is that they have relatively small financing deficits and small asset bases. Thus, the size of a debt issue required to cover the external financing needs is also small and would not warrant bearing the fixed cost of a public debt offering (Altinkilic and Hansen (2002)). In contrast, to these results, $71 \%$ of large firms with a high predicted probability of having access to public debt markets actually have a bond rating. ${ }^{10}$

\section{Asymmetric Information, Debt Capacity, and Financing Choice}

The pecking order (Myers (1984)) is derived based on the assumption that costs of asymmetric information drive firms' financing choices. Based on this, Frank and Goyal (2003) and Fama and French (2002) argue that firms with more asymmetric information should follow the pecking order more diligently. These studies cite the finding that small, high-growth firms are the predominant issuers of equity and the evidence that the Shyam-Sunder and Myers test performs poorly on a sample of small, high-growth firms and well on a sample of large, mature firms as inconsistent with the pecking order. Their conclusions are based on the observation that the former group of firms should face larger problems of asymmetric information than the latter.

While this intuition is appealing, it is important to note that the theoretical basis of the Myers and Majluf (1984) argument, the foundation of the pecking order, is the wealth loss to existing shareholders from new equity issues. This loss is derived from a comparison of the cost

\footnotetext{
${ }^{10}$ The proportion of firms with ratings in each group is computed only in the post-1985 period, when bond ratings become available on Compustat.
} 
due to asymmetric information concerning the assets in place versus the expected value of the firm's growth options relative to the value of the firm's assets in place. While small, highgrowth firms can reasonably be expected to have greater amounts of asymmetric information with respect to their assets in place than do large, mature firms, they can also reasonably be expected to have growth options that are more valuable relative to the value of assets in place. If the growth options of small firms are significantly more valuable (relative to assets in place) compared to those of large firms, then small firms, according to the Myers and Majluf (1984) model, may actually face lower adverse selection costs associated with an equity issue despite the higher levels of asymmetric information and so will find it less costly to deviate from the pecking order.

Furthermore, note that our model predicting whether a firm can issue rated debt finds firm size, age, and volatility to be major predictors of whether a firm will have rated debt outstanding. Our findings, therefore, indicate that all else equal, small and/or young firms are also much more likely to be constrained by concerns over debt capacity. Additionally, highgrowth firms with significant external financing needs, all else equal, will move toward their debt capacities more quickly if they issue debt to finance investment. The recognition that small, high-growth firms may have greater concerns over debt capacity implies that finding frequent equity issues by such firms is not necessarily contradictory to the pecking order.

To explore how debt capacity and costs of adverse selection affect financing behavior, we first compare firms that issue significant amounts of equity to those that do not. Table 7 presents summary statistics for firms sorted into three groups based upon their estimated probability of having a debt rating. ${ }^{11}$ These groups are further sorted into those firms that issue significant

\footnotetext{
${ }^{11}$ If we instead use firm age or volatility as a measure of debt capacity similar results are obtained.
} 
amounts of equity in a given year and those that do not. Using the Compustat data, we define a significant issue of equity as one that equals or exceeds five percent of the value of the firm's total assets at the end of the previous period. ${ }^{12}$ We refer to these firms as "issuers". ${ }^{13}$

For the subsample of firms most likely to face debt capacity constraints (the low predicted rating group) we find significant differences in the characteristics of issuers and nonissuers. Most dramatically we see that the issuers of significant amounts of equity are, on average, growing very fast (average growth in assets is $49.8 \%$ annually as compared to $10.6 \%$ for the non-issuers). Further, this growth is largely dependent upon external financing (the average financing deficit for issuers is $42.9 \%$ and their average return on assets is $-2.4 \%$ ).

Issuers also have relatively low leverage measured both by the $13.4 \%$ book leverage and the $-6.0 \%$ excess leverage. ${ }^{14}$ Although they have low leverage prior to the issue, the predicted leverage change (the change in the firm's book leverage ratio that would occur if their deficits completely financed with debt) of $29 \%$ is quite large, indicating that if these firms used only debt financing their debt ratios would on average increase from about $13 \%$ to over $42 \%$. Given their growth rates and negative profitability, such an increase in leverage would likely violate any reasonable expected level of debt capacity. ${ }^{15}$ In contrast, the actual financing choices of these

\footnotetext{
${ }^{12}$ The five percent cutoff for identifying issuers with Compustat data has also been used by Hovakimian et al. (2001), Korajczyk and Levy (2003), and Leary and Roberts (2004).

${ }^{13} \mathrm{All}$ of the differences in means between issuers and nonissuers of the variables reported in Table 6 are significant at the five percent level with the exception of lagged total assets and lagged property plant equipment for the low predicted rating group and lagged property plant equipment for the medium predicted rating group.

${ }^{14}$ Excess leverage is the difference between the firm's leverage ratio and the predicted value of leverage from a cross-sectional regression (based on all firms in the sample in that year) of leverage on log total assets, the ratio of property plant and equipment to total assets, market-to-book, return on assets, the predicted probability that a firm has bond rating from model (1) in Table 2, and indicator variables for each two-digit SIC code in the sample.

${ }^{15}$ Leary and Roberts (2007) find that, based on a comparison of ex ante firm characteristics, firms issuing equity in violation of the pecking order are predicted to be able to borrow at rates near those in the public debt markets. Based on this they argue that most violations of the pecking order by equity issuers are for reasons not related to debt capacity. Our findings suggest that small firms that issue equity would very likely violate their debt capacities were they to use debt rather than equity. We conjecture that the apparent discrepancy comes from the fact that the small firms represented in the Deal-Scan data base are those most likely to have rated debt.
} 
firms result in changes in leverage of essentially zero. In contrast, the nonissuers have a predicted leverage change of only $2.7 \%$ and an actual leverage change of $1.7 \%$. Finally, compared to non-issuers, the issuers are smaller (\$16.7 Million in assets vs. \$17.4 Million), younger (6.3 vs. 9.2 years), have higher market-to-book ratios (3.4 vs. 1.6), and higher volatility of stock returns (0.84 vs. 0.71$)$. Given their characteristics, it is not too surprising that these firms use equity rather than debt financing.

Issuing firms with medium and high estimated probabilities of having a bond rating should be less likely to be rationed by lenders, but may be reluctant to pursue further borrowing because they are unable to support additional debt. Consistent with this view, the issuing firms in these groups are growing much more rapidly and have significantly higher leverage prior to the issue than similar nonissuers. As a specific example, consider the firms in the high predicted rating group. Within this subsample, the firms issuing significant amounts of equity have leverage of $37.8 \%$ and excess leverage of $10.4 \%$. The predicted change in leverage (based on no new equity) is $7.4 \%$, which would push these firms, on average, to a book leverage of $45 \%$. Instead, the actual financing choices made by these firms result in reductions in their book leverage ratios by an average of $5.1 \%$. In contrast, non-issuers in the high predicted rating group have average leverage of $29 \%$ ( $2.2 \%$ excess leverage) and a predicted leverage change of $0.5 \%$. This predicted leverage change is very close to their actual change in leverage of $0.4 \%$.

Note that, across all three groups of firms, there is a clear pattern comparing issuers versus non-issuers. Issuers are younger firms that are growing much more rapidly. They also have more volatile stock returns (indicating more volatile cash flows) and are less profitable. In the highest and lowest groups, the issuers are also smaller firms, on average, with the issuers and non-issuers being of about equivalent size in the medium group. These results provide additional 
empirical validation of the use of the predicted bond rating variable as a measure of debt capacity. They also suggest that those firms who issue the majority of external equity can be classified as constrained by concerns over debt capacity, and provide a reconciliation of the results in Fama and French (2002) and Frank and Goyal (2003) with the pecking order.

Finally, we examine whether small, high-growth firms face higher or lower adverse selection costs associated with equity issues as measured by the market reaction to the announcement of an equity issue. ${ }^{16}$ To the extent that small, high-growth firms have significant growth opportunities and are constrained from issuing debt, the market should react less negatively to the announcement of an equity issue for these firms. In order to measure the cost of an equity issue we examine announcement effects for all issues of seasoned equity for firms in our sample with announcements of equity issues reported in the SDC database between 1980 and 2001. ${ }^{17}$ We measure the three-day cumulative abnormal return (CARs) around equity issue announcements relative to a market model estimated over the 200-day period ending 21 days prior to the announcement of the equity issue. The final sample consists of 2,275 equity issue announcements, and the average three-day announcement CAR in the sample is -0.026 .

The first two columns of Table 8 present the results of cross-sectional regressions explaining the announcement CARs using the market-to-book ratio, leverage, the fraction of secondary shares in the issue, and indicators for each sample year as control variables. We create an indicator variable equal to one for firms in the low predicted bond rating group. In addition to identifying the firms most likely to be concerned about debt capacity, the summary

\footnotetext{
${ }^{16}$ In an empirical examination of the Myers and Majluf (1984) model Korajczyk, Lucas, and McDonald present evidence consistent with the idea that announcement effects are driven by adverse selection.

${ }^{17}$ Note that the SDC sample contains fewer equity issues than in Table 6. This is because Table 6 defines equity issues based on the statement of cash flows, and includes equity transactions, such as private equity issues and debt conversions, beyond those reported in SDC. Hovakimian, et al. (2001) discusses this issue in more detail.
} 
statistics presented in Table 7 clearly indicate that firms with the lowest estimated probability of having a bond rating are also the smallest, youngest, and fastest growing firms. We examine their costs of issuing equity relative to other firms in order to explore the validity of the idea that firms in this group have the greatest exposure to the cost of asymmetric information and therefore, should have an incentive to follow the static pecking order more closely.

The first column in Table 8 examines the full sample of equity issuers, while the second estimates the regression on a sample restricted to include only those firms that make significant issues of equity (based on the 5\% cutoff used previously). In both cases we see that, on average, the constrained firms have significantly less negative market reactions to announcements of equity issues compared to other firms. All else equal, the firms in the low predicted rating group see their stock prices fall by about $1 \%$ less relative to other firms at the announcement of an equity issue. Columns three and four repeat the analysis, but use a different dependent variable to measure the market reaction to an issue of equity. The result in Myers and Majluf (1984) is driven by the wealth loss to existing shareholders rather than simply the CAR. We follow Stein (1992) and compute the dollar loss to existing shareholders (equal to the market value of equity prior to the issue multiplied by the CAR) scaled by the proceeds of the issue. ${ }^{18}$ Based on this measure of the cost of an equity issue we again see that the firms who are most likely to be constrained by concerns over debt capacity face lower costs compared to other firms at the announcement of an equity issue. On average, the existing shareholders of firms in the low predicted rating group face a cost associated with a new equity issue that is $\$ 0.085$ (per dollar raised) lower than do the shareholders of other issuing firms.

The results are consistent with three interpretations. The first is that although the small,

\footnotetext{
${ }^{18}$ If we do not scale by the proceeds of the issue the same qualitative results are obtained.
} 
high-growth firms in the low predicted rating group may face more asymmetric information concerning the value of their assets in place, they also face relatively more valuable investment opportunity sets. The second is that the market realizes that, due to the constraint imposed by debt capacity, the firm has little or no flexibility in its choice of financing instruments and so the announcement of an equity issue is less of a negative signal than it would be for a similar firm that could also choose to issue debt. Finally, if small, high-growth firms are better at "timing" their equity issues we would also expect to see this pattern. It is difficult to control for timing ability, however, given the differences in growth rates (which is correlated with the demand for external financing) between these firms and the rest of the sample, the small, high-growth firms should also have less flexibility in choosing when to issue than more mature firms.

As a final point, some caution should be used in interpreting these results as we only observe the market reactions of those firms that have chosen to issue equity. This selection bias makes it less likely for us to find any significant differences across the groups of firms.

Nonetheless, our results provide a rationale within the pecking order framework for the frequent equity issues by small, high-growth firms, which others have posed as a challenge to the theory.

\section{Conclusion}

We demonstrate the importance of controlling for debt capacity when testing the pecking order theory. When we control for heterogeneity in debt capacity across firms we find that the pecking order theory is a good descriptor of the observed financing behavior of a broad crosssection of firms and provide a reconciliation of apparently conflicting findings in the literature that question the ability of the pecking order to describe the financing behavior of firms. Furthermore, we present evidence based on differences in firm characteristics and from market 
reactions to equity issues that reconcile the observed patterns of equity issuance across large, mature versus small, high-growth firms with the pecking order. The demonstrated preference of small, high-growth firms for equity finance is explained by their growth levels and restrictive debt capacity constraints. When firms such as these seek equity financing they actually experience a lower price drop at the announcement of the offering despite the greater amount of asymmetric information concerning the values of these firms.

An issue left to future research is the interaction between the growth in assets, profitability, and financing. We have implicitly assumed that asset growth and profitability are exogenous to the financing decision in this analysis. Theoretically, with perfect markets, this would be correct. Once one assumes a role for capital structure, however, we are necessarily removed from the Modigliani and Miller world, and it would be interesting and important to explore the link between a firm's financing and capital budgeting decisions. 


\section{Appendix}

\section{Pecking Order Simulations}

The pecking order with debt capacity assumes that a given financing deficit will be filled with debt up to the point that a firm exhausts its debt capacity and the remainder will be filled using equity. Formally:

$$
\operatorname{Debt}_{i t}=\left\{\begin{array}{l}
D e f_{i t}, \text { if } D e f_{i t} \leq D_{i t}^{*} \\
D_{i t}^{*}, \text { if } D e f_{i t}>D_{i t}^{*}
\end{array}\right.
$$

where $D e b t_{i t}$ is the amount of debt issued, $D e f_{i t}$ is the financing deficit, and $D_{i t}^{*}$ is the incremental debt capacity of firm i in period t. We parameterize the simulations by specifying the first and second moments of the financing deficit and debt capacity. Specifically, we require estimates of the mean vector of $\left(D e f_{i t}, D_{i t}^{*}\right)$ and of the covariance matrix, which we denote by

$$
V=\left[\begin{array}{cc}
\sigma_{D e f}^{2} & \sigma_{D e f, D^{*}} \\
\sigma_{D e f, D^{*}} & \sigma_{D^{*}}^{2}
\end{array}\right]
$$

To simulate financing behavior we use the actual financing deficits of firms from the data and draw observations for debt capacity based on the following:

$$
\begin{aligned}
& D_{i t}^{*}=\operatorname{Max}\left(0, a+b * D e f_{i t}+c \tilde{v}_{i t}\right), \\
& \text { where } \tilde{v}_{i t} \sim N(0,1)
\end{aligned}
$$

In the actual data, debt capacity is unobservable, but the amount of debt actually issued, Debt $t_{i t}$, is observable. To calibrate the simulations, we choose the parameters $a, b$, and $c$ in (A3) such that the first and second moments of the simulated debt issues as parameterized in (A1) and the correlation coefficient between the simulated debt issues and the financing deficit match with the values in the actual data. We parameterize the simulations separately for two sets of firms using 
our measure of debt capacity based on the likelihood of having a bond rating. Specifically, we simulate financing decisions for firms in the lowest third (low debt capacity) and firms in the highest third (high debt capacity) of the distribution of predicted bond ratings. For each observation of the financing deficit we simulate a value for debt capacity from (A3) and a debt issuance decision that corresponds to the pecking order as parameterized in equation (A1).

In addition to the financing behavior simulated under the pecking order we follow Leary and Roberts (2007) and also simulate financing behavior under a random financing rule. Specifically, for each draw of the financing deficit we simulate a debt issuance decision according to the following rule

$$
\operatorname{Debt}_{i t}=\left\{\begin{array}{l}
\operatorname{Def}_{i t}, \text { if } \tilde{U} \leq \bar{C} \\
0, \quad \text { if } \tilde{U}>\bar{C}
\end{array}\right.
$$

where $\tilde{U}$ is a draw from a uniform $(0,1)$ distribution and $\bar{C}$ is a parameter that we choose such that the proportion of debt and equity issues match those in the sample. Under the random financing rule, the firm's financing decisions are independent of the size of the financing deficit and of the firm’s debt capacity.

Finally, we also simulate data based on a partial adjustment model consistent with the tradeoff theory of capital structure. Specifically, we use the actual financing deficits and retained earnings in the data to determine the amounts of debt and equity issued each period according to the partial adjustment model in equation (3). We set the speed of adjustment, $k$, equal to 0.3 , and use the sample average mean value of leverage in each group (constrained and unconstrained) as the target value of leverage.

The simulated financing data under all financing rules, pecking order, random, and partial adjustment is then used to estimate the Shyam-Sunder and Myers (1999) regression in equation 
(1) and our augmented version of the regression in equation (2). The results are reported in Table 1. 


\section{References}

Altinkilic, O., and R. Hansen, 2000, "Are There Economies of Scale in Underwriting Fees?

Evidence of Rising External Financing Costs,” Review of Financial Studies 13, 191-218.

Barcaly, M., E. Morellec, and C. Smith Jr., 2001, “On the Debt Capacity of Growth Options,” University of Rochester working paper.

Bolton, P., and X. Freixas, 2000, "Equity, Bonds, and Bank Debt: Capital Structure and Financial Market Equilibrium under Asymmetric Information," Journal of Political Economy $108,324-351$.

Brennan, M. and A. Kraus, 1987, "Efficient Financing under Asymmetric Information,” Journal of Finance 42, 1225-1243.

Cantillo, M., and J. Wright, 2000, "How Do Firms Choose Their Lenders? An Empirical Examination," Review of Financial Studies 13, 155-190.

Carpenter, R., S. Fazzari, and B. Peterson, 1998, "Financing Constraints and Inventory Investment: A Comparative Study with High-Frequency Panel Data," Review of Economics and Statistics 80, 513-519.

Chang, X. and S. Dasgupta, 2003, “Capital Structure Theories: Some New Tests,” Hong Kong University of Science and Technology working paper.

Chirinko, R. And A. Singha, 2000, "Testing Static Tradeoff Against Pecking Order Models of Capital Structure: A Critical Comment,” Journal of Financial Economics 58, 412-425.

Dybvig, P. H. and J. F. Zender, 1991, "Capital Structure and Dividend Irrelevance with Asymmetric Information,” Review of Financial Studies 4, 201-219.

Fama, E. F. and K. R. French, 2002, “Testing Trade-Off and Pecking Order Predictions About Dividends and Debt,” Review of Financial Studies15, 1-33.

Faulkender, M. and M. A. Petersen, 2006, "Does the Source of Capital Affect Capital Structure?” Review of Financial Studies 19, 45-79.

Fischer, E., R. Heinkel, and J. Zechner, 1989, "Dynamic Capital Structure Choice: Theory and Tests,” The Journal of Finance 44, 19-40.

Frank, M. and V. Goyal, 2003, “Testing the Pecking Order Theory of Capital Structure,” Journal of Financial Economics 67, 217-248.

Graham, J., 1996, “Debt and the Marginal Tax Rate,” Journal of Financial Economics 41, 41-73. 
Hellmann, T. And J. Stiglitz, 2003, "Credit and Equity Rationing in Markets with Adverse Selection,” Stanford University working paper.

Holmstrom, B., and J. Tirole, 1997, "Financial Intermediation, Loanable Funds, and the Real Sector,” Quarterly Journal of Economics 112, 663 - 691.

Hovakimian, A., T. Opler, and S. Titman, 2001, “The Debt-Equity Choice,” Journal of Financial and Quantitative Analysis 36, 1-24.

Korajczyk, R. A., D. J. Lucas, and R. L. McDonald, 1991, “The Effect of Information Releases on the Pricing and Timing of Equity Issues,” Review of Financial Studies 4, 685-708.

Korajczyk, R. A., and A. Levy, 2003, “Capital Structure Choice: Macroeconomic Conditions and Financial Constraints,” Journal of Financial Economics 68, 75-109.

Leary, M. T. and M. R. Roberts, 2005, “Do Firms Rebalance Their Capital Structures?,” Journal of Finance 60, 2575 - 2619.

Leary, M. T. and M. R. Roberts, 2007, “The Pecking Order, Debt Capacity, and Information Asymmetry,” University of Pennsylvania working paper.

Myers, S., 1977, “Determinants of Corporate Borrowing,” Journal of Financial Economics 5, 147-175.

Myers, S., 1984, “The Capital Structure Puzzle,” Journal of Finance 39, 575-592.

Myers, S. and N. Majluf, 1984, “Corporate Financing and Investment Decisions When Firms Have Information that Investors Do Not Have,” Journal of Financial Economics13, 187-221.

Shyam-Sunder, L. and S. Myers, 1999, “Testing Static Tradeoff Against Pecking Order Models of Capital Structure,” Journal of Financial Economics 51, 219-244.

Stein, J., 1992, “Convertible Bonds as Backdoor Equity Financing,” Journal of Financial Economics 32, 3-21.

Stiglitz, J. and A. Weiss, 1981, "Credit Rationing in Markets and Imperfect Information,” American Economic Review, 71, 393-410.

Whited, T., 1992, “Debt, Liquidity Constraints, and Corporate Investment: Evidence from Panel Data,” Journal of Finance 47, 1425-1460. 
Table 1

Shyam Sunder-Myers regressions based on simulated financing behavior under the pecking order with debt capacity, under random financing, and under a partial adjustment model with adjustment speed paramater $(\lambda)$ equal to 0.3 .

Panel A. Simulated Financing Behavior Under Pecking Order With Debt Capacity Dependent Variable is Simulated Net Debt Issued

Variable Low Debt Capacity

\begin{tabular}{lcccc}
\hline Intercept & -0.009 & -0.013 & -0.010 & -0.010 \\
& $(-16.71)$ & $(-38.61)$ & $(-40.43)$ & $(-32.70)$ \\
Financing Deficit & 0.316 & 0.538 & 0.772 & 0.787 \\
Squared Financing Deficit & $(31.03)$ & $(37.57)$ & $(73.66)$ & $(84.95)$ \\
& --- & -0.226 & -- & -0.026 \\
& & $(-12.61)$ & & $(-1.20)$ \\
$\mathrm{N}$ & & 22,401 & 22,401 & 22,401 \\
R-Squared & 22,401 & 0.415 & 0.818 & 0.818 \\
\hline
\end{tabular}

Panel B. Simulated Financing Behavior Under Random Financing Dependent Variable is Simulated Net Debt Issued

\begin{tabular}{|c|c|c|c|c|}
\hline \multirow{2}{*}{$\frac{\text { Variable }}{\text { Intercept }}$} & \multicolumn{2}{|c|}{ Low Debt Capacity } & \multicolumn{2}{|c|}{ High Debt Capacity } \\
\hline & 0.001 & 0.001 & 0.000 & 0.000 \\
\hline & $(2.33)$ & (1.96) & $(-0.42)$ & $(-0.95)$ \\
\hline \multirow[t]{2}{*}{ Financing Deficit } & 0.298 & 0.342 & 0.760 & 0.732 \\
\hline & (22.16) & (19.26) & (49.57) & (52.17) \\
\hline \multirow[t]{2}{*}{ Squared Financing Deficit } & --- & -0.045 & --- & 0.050 \\
\hline & & $(-1.78)$ & & $(1.46)$ \\
\hline $\mathrm{N}$ & 22,401 & 22,401 & 22,401 & 22,401 \\
\hline R-Squared & 0.275 & 0.277 & 0.753 & 0.754 \\
\hline \multicolumn{5}{|c|}{ Panel C. Simulated Financing Behavior Under Partial Adjustment Model $(\lambda=0.3)$} \\
\hline \multirow[b]{2}{*}{ Variable } & \multicolumn{4}{|c|}{ Dependent Variable is Simulated Net Debt Issued } \\
\hline & \multicolumn{2}{|c|}{ Low Debt Capacity } & \multicolumn{2}{|c|}{ High Debt Capacity } \\
\hline \multirow[t]{2}{*}{ Intercept } & 0.002 & 0.002 & -0.002 & -0.002 \\
\hline & $(2.71)$ & $(2.51)$ & $(-2.38)$ & $(-2.10)$ \\
\hline \multirow[t]{2}{*}{ Financing Deficit } & 0.057 & 0.070 & 0.071 & 0.090 \\
\hline & $(9.05)$ & $(7.27)$ & $(6.08)$ & $(6.48)$ \\
\hline \multirow[t]{2}{*}{ Squared Financing Deficit } & --- & -0.014 & --- & -0.035 \\
\hline & & $(-1.27)$ & & $(-1.76)$ \\
\hline $\mathrm{N}$ & 22,401 & 22,401 & 22,401 & 22,401 \\
\hline R-Squared & 0.011 & 0.012 & 0.006 & 0.006 \\
\hline
\end{tabular}


Table 2

Logit regressions predicting bond ratings. The dependent variable is an indicator equal to one if the firm has a bond rating from Compustat in that year. The independent variables include the natural log of total book assets, return on assets, the fraction of total assets in property plant and equipment, the market-to-book ratio and leverage,. All explanatory variables are lagged one period. Model (2) includes indicator variables for each two-digit SIC code. The initial sample consists of 67,200 firm-year observations from the period 1971-2001. The subsample of firms used in the regressions is from 1986-2001, the time period that bond ratings are available on Compustat. z-statistics based on robust standard errors adjusted for nonindependence of observations within firms are reported in parentheses.

\begin{tabular}{lcc}
\hline \multirow{2}{*}{ Variable } & \multicolumn{2}{c}{ Dependent Variable is one if the firm has a bond rating in that year } \\
Model (1) & Model (2) \\
\hline Intercept & -10.048 & -10.234 \\
Log (Assets) & $(-30.91)$ & $(-19.29)$ \\
& 1.212 & 1.238 \\
Return on Assets & $(25.49)$ & $(24.75)$ \\
& 0.028 & 0.237 \\
Property Plant \& Equipment & $(0.07)$ & $(0.57)$ \\
& -0.136 & -0.702 \\
Market-to-Book & $(-0.63))$ & $(-2.44)$ \\
& -0.077 & -0.054 \\
Leverage & $(-2.17)$ & $(-1.57)$ \\
& 3.917 & 4.052 \\
Log(Firm Age) & $(13.66)$ & $(14.96)$ \\
Standard Deviation of & 0.363 & 0.391 \\
Stock Returns & $(6.36)$ & $(6.64)$ \\
Industry Indicators & -4.944 & -5.619 \\
\hline $\mathrm{N}$ & $(-2.43)$ & $(-2.72)$ \\
Pseudo R-Squared & No & Yes \\
\hline
\end{tabular}


Table 3

Summary statistics for subsamples of firms with and without bond ratings reported in Compustat. The initial sample consists of 67,200 firm-year observations for 1971-2001. The sample reported in the table contains only data for firms with the lowest and highest predicted probabilities of having a bond rating computed from model (1) from the logit regressions in Table 2. The financing deficit and net debt and equity issues are defined using the flow of funds data on Compustat. Firm age is measured relative to the first year the firm appears on Compustat. The predicted change in leverage is the change in the firm's leverage ratio over the year if the firm financed its entire financing deficit with debt.

\begin{tabular}{|c|c|c|c|c|c|c|c|c|}
\hline \multirow[t]{2}{*}{ Variable } & \multicolumn{4}{|c|}{ Low Predicted Bond Rating $(\mathrm{N}=22,401)$} & \multicolumn{4}{|c|}{ High Predicted Bond Rating $(\mathrm{N}=22,401)$} \\
\hline & Mean & Std. Dev. & 25th Pctile & 75th Pctile & Mean & Std. Dev. & 25th Pctile & 75th Pctile \\
\hline Financing Deficit/Total Assets & 0.081 & 0.241 & -0.015 & 0.077 & 0.027 & 0.139 & -0.026 & 0.049 \\
\hline Net Debt Issued/Total Assets & 0.026 & 0.134 & -0.015 & 0.019 & 0.021 & 0.122 & -0.021 & 0.042 \\
\hline Net Equity Issued/Total Assets & 0.055 & 0.204 & 0.000 & 0.011 & 0.006 & 0.070 & -0.001 & 0.004 \\
\hline Three Year Average Future Financing Deficit & 0.068 & 0.144 & -0.008 & 0.093 & 0.023 & 0.084 & -0.017 & 0.045 \\
\hline Growth in Total Assets & 0.164 & 0.421 & -0.034 & 0.262 & 0.100 & 0.246 & -0.009 & 0.159 \\
\hline Three Year Average Future Asset Growth & 0.159 & 0.246 & 0.019 & 0.249 & 0.100 & 0.153 & 0.017 & 0.156 \\
\hline Firm Age (Years) & 8.740 & 6.423 & 4.000 & 12.000 & 21.655 & 12.171 & 11.000 & 30.000 \\
\hline Total Assets & 20.566 & 21.040 & 8.350 & 26.058 & 2294.583 & 7194.108 & 257.450 & 1582.725 \\
\hline Net Prop. Plant \& Equip./Total Assets & 0.267 & 0.200 & 0.118 & 0.361 & 0.405 & 0.217 & 0.234 & 0.564 \\
\hline Market-to-Book Ratio & 1.748 & 1.947 & 0.865 & 1.895 & 1.453 & 0.936 & 0.982 & 1.596 \\
\hline Return on Assets & 0.073 & 0.237 & 0.016 & 0.192 & 0.137 & 0.126 & 0.097 & 0.183 \\
\hline Annual Standard Deviation of Stock Returns & 0.733 & 0.468 & 0.449 & 0.880 & 0.434 & 0.245 & 0.281 & 0.511 \\
\hline Long-Term Debt/Total Assets & 0.129 & 0.149 & 0.004 & 0.206 & 0.296 & 0.256 & 0.162 & 0.390 \\
\hline Change in Leverage & 0.014 & 0.104 & -0.020 & 0.026 & -0.001 & 0.175 & -0.032 & 0.026 \\
\hline Predicted Change in Leverage & 0.065 & 0.204 & -0.014 & 0.095 & 0.010 & 0.450 & -0.028 & 0.040 \\
\hline
\end{tabular}


Table 4

Pooled time-series cross-section regressions of net debt issued on the current financing deficit and the squared value of the current financing deficit. Net debt issues and the financing deficit are computed using flow of funds data from Compustat. All variables are scaled by total assets at the end of the previous year. The sample consists of 67,203 firm-year observations from the period 19712001. Firms are sorted into subsamples based on the predicted probability that the firm has a bond rating computed from model (1) from the logit regressions in Table 2. t-statistics based on robust standard errors adjusted for nonindependence within firms are reported in parentheses.

\begin{tabular}{|c|c|c|c|c|c|c|}
\hline \multicolumn{7}{|c|}{ Subsamples Based On Predicted Bond Ratings } \\
\hline \multirow{3}{*}{$\frac{\text { Variable }}{\text { Intercept }}$} & \multicolumn{6}{|c|}{ Dependent Variable is Net Debt Issued } \\
\hline & \multicolumn{2}{|c|}{ Low } & \multicolumn{2}{|c|}{ Medium } & \multicolumn{2}{|c|}{ High } \\
\hline & 0.002 & -0.002 & -0.002 & -0.002 & 0.000 & 0.001 \\
\hline & $(3.00)$ & $(-3.85)$ & $(-3.44)$ & $(-3.17)$ & $(0.92)$ & (1.48) \\
\hline \multirow[t]{2}{*}{ Financing Deficit } & 0.297 & 0.527 & 0.620 & 0.674 & 0.755 & 0.787 \\
\hline & $(25.34)$ & (34.89) & (39.43) & (34.89) & $(60.07)$ & $(59.61)$ \\
\hline \multirow[t]{2}{*}{ Squared Financing Deficit } & --- & -0.236 & & -0.076 & --- & -0.056 \\
\hline & & $(-12.61)$ & & $(-2.24)$ & & $(-2.15)$ \\
\hline $\mathrm{N}$ & 22,401 & 22,401 & 22,401 & 22,401 & 22,401 & 22,401 \\
\hline R-Squared & 0.286 & 0.337 & 0.602 & 0.601 & 0.750 & 0.752 \\
\hline
\end{tabular}


Pooled time-series cross-section regressions of net debt issued on the current financing deficit and the squared value of the current financing deficit. Net debt issues and the financing deficit are computed using flow of funds data from Compustat. All variables are scaled by total assets at the end of the previous year. The sample consists of 67,203 firm-year observations from the period 1971-2001. Firms are sorted into subsamples based on the predicted probability that the firm has a bond rating computed from model (1) from the logit regressions in Table 2. Results for the middle tercile of reported bond ratings are not reported. Firms in financial distress are defined as those with values of Altman's Z-score below the 25th percentile. t-statistics based on robust standard errors adjusted for nonindependence within firms are reported in parentheses.

\begin{tabular}{|c|c|c|c|c|c|c|}
\hline \multicolumn{7}{|c|}{ Subsamples Based On Predicted Bond Ratings } \\
\hline \multirow[b]{3}{*}{ Variable } & \multicolumn{6}{|c|}{ Dependent Variable is Net Debt Issued } \\
\hline & \multicolumn{2}{|c|}{ Excluding Negative Deficits } & \multicolumn{2}{|c|}{ Excluding Negative ROA } & \multicolumn{2}{|c|}{ Excluding Financial Distress } \\
\hline & Low & High & Low & High & Low & High \\
\hline \multirow[t]{2}{*}{ Intercept } & 0.009 & 0.002 & 0.001 & 0.010 & 0.001 & 0.006 \\
\hline & $(6.47)$ & $(1.25)$ & $(2.72)$ & $(2.10)$ & $(3.31)$ & $(10.50)$ \\
\hline \multirow[t]{2}{*}{ Financing Deficit } & 0.469 & 0.776 & 0.588 & 0.783 & 0.494 & 0.690 \\
\hline & $(20.20)$ & $(29.31)$ & $(32.02)$ & $(57.50)$ & (29.09) & $(30.77)$ \\
\hline \multirow[t]{2}{*}{ Squared Financing Deficit } & -0.197 & -0.044 & -0.255 & -0.022 & -0.217 & 0.039 \\
\hline & $(-8.18)$ & $(-1.13)$ & $(-9.76)$ & $(0.90)$ & $(-10.62)$ & $(0.85)$ \\
\hline $\mathrm{N}$ & 11,918 & 22,343 & 17,675 & 21,731 & 19,041 & 15,113 \\
\hline R-Squared & 0.215 & 0.714 & 0.388 & 0.761 & 0.310 & 0.699 \\
\hline
\end{tabular}


Table 6

Shyam Sunder-Myers regressions for firms classified into subsamples based firm size and probability of having a bond rating. Net debt issues and the financing deficit are computed using flow of funds data from Compustat. All variables are scaled by total assets at the end of the previous year. The sample consists of 67,203 firm-year observations from the period 1971-2001. Firms are sorted into two firm size groups based on the value of total assets in each year. Then within each firm size group firms are sorted into three groups based on the predicted probability of having a bond rating computed from model (1) from the logit regressions in Table 2. t-statistics based on robust standard errors adjusted for nonindependence within firms are reported in parentheses.

\begin{tabular}{|c|c|c|c|}
\hline \multirow[b]{3}{*}{ Variable } & \multirow{2}{*}{\multicolumn{3}{|c|}{ Predicted Bond Ratings }} \\
\hline & & & \\
\hline & Low & Medium & High \\
\hline \multirow[t]{2}{*}{ Intercept } & -0.001 & -0.002 & -0.006 \\
\hline & $(-1.78)$ & $(-3.68)$ & $(-6.69)$ \\
\hline \multirow[t]{2}{*}{ Financing Deficit } & 0.477 & 0.580 & 0.687 \\
\hline & (23.45) & (25.38) & (33.11) \\
\hline \multirow[t]{2}{*}{ Squared Financing Deficit } & -0.221 & -0.215 & -0.114 \\
\hline & $(-9.91)$ & $(-5.67)$ & $(-2.76)$ \\
\hline $\mathrm{N}$ & 11,203 & 11,203 & 11,204 \\
\hline R-Squared & 0.288 & 0.410 & 0.586 \\
\hline \multicolumn{4}{|l|}{ Panel B. Large firms } \\
\hline & \multicolumn{3}{|c|}{ Predicted Bond Ratings } \\
\hline Variable & Low & Medium & High \\
\hline \multirow[t]{2}{*}{ Intercept } & 0.002 & -0.001 & 0.002 \\
\hline & (2.99) & $(-0.26)$ & (3.84) \\
\hline \multirow[t]{2}{*}{ Financing Deficit } & 0.657 & 0.772 & 0.790 \\
\hline & $(23.40)$ & $(47.10)$ & $(37.90)$ \\
\hline \multirow[t]{2}{*}{ Squared Financing Deficit } & -0.040 & -0.068 & 0.014 \\
\hline & $(-0.74)$ & $(-1.82)$ & $(0.52)$ \\
\hline $\mathrm{N}$ & 11,197 & 11,198 & 11,198 \\
\hline R-Squared & 0.627 & 0.732 & 0.796 \\
\hline
\end{tabular}


Summary statistics for subsamples of firms issuing and not issuing significant amounts of equity sorted by predicted bond rating groups. The predicted rating groups are formed based on the predicted probability of the firm having a bond rating from model (1) in Table 3. The financing deficit and net debt and equity issues computed using flow of funds data from Compustat. The financing variables are scaled by total assets at the end of the previous year. Issuers are defined as those firm-years where net equity issues exceed $5 \%$ of the firm's total assets at the end of the previous period. Excess leverage is the difference between the firm's leverage ratio and the predicted value of leverage from a cross-sectional regression (based on all firms in the sample in that year) of leverage on log total assets, the ratio of property plant and equipment to total assets, market-to-book, return on assets, the predicted probability that a firm has bond rating from model (1) in Table 2, and indicator variables for each two-digit SIC code in the sample.The initial sample consists of 67,200 firm-year observations from the period 1971-2001.

\begin{tabular}{|c|c|c|c|c|c|c|}
\hline \multirow{2}{*}{$\begin{array}{l}\text { Predicted Rating Group } \\
\text { Variable }\end{array}$} & \multicolumn{2}{|c|}{ Low } & \multicolumn{2}{|c|}{ Medium } & \multicolumn{2}{|c|}{ High } \\
\hline & Non-issuers & Issuers & Non-issuers & Issuers & Non-issuers & Issuers \\
\hline Net Debt Issued/Total Assets & 0.025 & 0.031 & 0.024 & 0.031 & 0.020 & 0.036 \\
\hline Lagged Leverage & 0.112 & 0.134 & 0.202 & 0.246 & 0.290 & 0.378 \\
\hline Excess Leverage & -0.080 & -0.060 & 0.025 & 0.077 & 0.022 & 0.104 \\
\hline Change in Leverage & 0.017 & -0.003 & 0.008 & -0.035 & 0.004 & -0.051 \\
\hline Growth in Assets & 0.106 & 0.498 & 0.100 & 0.443 & 0.083 & 0.332 \\
\hline Lagged Total Assets & 17.405 & 16.765 & 82.948 & 85.338 & 2190.405 & 1270.262 \\
\hline Lagged Return on Assets & 0.107 & -0.024 & 0.138 & 0.101 & 0.143 & 0.114 \\
\hline Lagged Market to Book & 1.580 & 3.372 & 1.404 & 2.285 & 1.448 & 1.729 \\
\hline Lagged Property Plant \& Equipment & 0.261 & 0.262 & 0.320 & 0.325 & 0.404 & 0.434 \\
\hline Age & 9.168 & 6.260 & 13.864 & 9.809 & 22.042 & 16.570 \\
\hline
\end{tabular}


Table 8

Regression analysis of market reaction to equity issue announcements. The dependent variable in the regressiosn is either the three-day cumulative abnormal returns around equity issue announcements or the dollar loss to existing shareholders scaled by proceeds of the offering. Independent variables include an indicator for firms in the low predicted bond rating group defined based on the probability of having a bond rating from model (1) in Table 3, the natural log of the issue proceeds, market-to-book, leverage, the fraction of secondary shares in the issue, and indicators for each year. Abnormal returns are estimated over the three-day period \{$1,1\}$ surrounding the issue announcement based on residuals from a market model estimated over the period beginning 220 days and ending 21 days prior to the announcement. Equity issue announcements come from the Securities Data Corporation New Issues Database and cover the years 1980-2001. Large issuers are classified as those where the proceeds from the issue are greater than $5 \%$ of total book assets measured at the end of the year prior to the issue. The initial sample consists of 67,200 firm-year observations from the period 1971-2001. t-statistics based on robust standard errors are reported in parentheses.

\begin{tabular}{|c|c|c|c|c|}
\hline & \multicolumn{3}{|c|}{ Large Issuers } & \multirow{3}{*}{$\begin{array}{l}\text { Large Issuers } \\
\text { Only } \\
\text { Dollar Loss }\end{array}$} \\
\hline & All Issuers & Only & All Issuers & \\
\hline & $\operatorname{CAR}\{-1,+1\}$ & CAR $\{-1,+1\}$ & Dollar Loss & \\
\hline \multirow[t]{2}{*}{ Intercept } & -0.044 & -0.032 & -0.177 & -0.074 \\
\hline & $(3.81)$ & $(-0.91)$ & $(-2.68)$ & $(-0.43)$ \\
\hline \multirow[t]{2}{*}{ Low Predicted Rating Group } & 0.009 & 0.012 & 0.085 & 0.085 \\
\hline & $(2.52)$ & (2.99) & $(4.31)$ & $(4.21)$ \\
\hline \multirow[t]{2}{*}{ Log(Proceeds) } & 0.003 & 0.005 & 0.002 & 0.008 \\
\hline & $(1.96)$ & $(2.92)$ & $(0.31)$ & $(0.97)$ \\
\hline \multirow[t]{2}{*}{ Market-to-Book Ratio } & -0.002 & -0.002 & -0.013 & -0.009 \\
\hline & $(-2.66)$ & $(-1.80)$ & $(-2.84)$ & $(-1.82)$ \\
\hline \multirow[t]{2}{*}{ Leverage } & 0.005 & 0.002 & 0.053 & 0.051 \\
\hline & $(0.68)$ & $(0.29)$ & $(1.37)$ & $(1.28)$ \\
\hline \multirow[t]{2}{*}{ Fraction Secondary Shares } & -0.005 & -0.015 & -0.043 & -0.046 \\
\hline & $(-1.51)$ & $(-2.80)$ & $(-2.16)$ & $(-1.67)$ \\
\hline Year Dummies & Yes & Yes & Yes & Yes \\
\hline $\mathrm{N}$ & 2,275 & 1,932 & 2,126 & 1,840 \\
\hline R-Squared & 0.014 & 0.018 & 0.024 & 0.020 \\
\hline
\end{tabular}

